\title{
Low-Level Laser Therapy and Topical Medications for Treating Aphthous Ulcers: A Systematic Review
}

This article was published in the following Dove Press journal: Journal of Multidisciplinary Healthcare

\author{
Mohammed Khaleel Ahmed' \\ Mohammed Jafer (D) ${ }^{2}$ \\ Maryam Nayeem ${ }^{3}$ \\ Ibtisam Hussain Moafa $\left.{ }^{4}\right)^{4}$ \\ Mir Furruq Ali Quadri ${ }^{5}$ \\ Hema Gopalaiah' \\ Mir Faeq Ali Quadri $\mathbb{D}^{2}$ \\ 'Department of Oral Medicine and \\ Radiology, M.N.R Dental College, India; \\ ${ }^{2}$ Department of Preventive Dental \\ Sciences, College of Dentistry, Jazan \\ University, Saudi Arabia; ${ }^{3}$ Department of \\ Pharmacology, College of Pharmacy, Jazan \\ University, Saudi Arabia; ${ }^{4}$ Care and Public \\ Health Research Institute, Faculty of \\ Health, Medicine and Life Sciences, \\ Maastricht University, the Netherlands; \\ ${ }^{5}$ Department of Internal Medicine, Lister \\ Hospital, East and North Hertfordshire, \\ NHS Trust, Stevenage, UK
}

Correspondence: Mir Faeq Ali Quadri Department of Preventive Dental Sciences, College of Dentistry, Jazan University, PO Box: II4, Jazan 45I42, Saudi Arabia

Tel +966598959409

Email dr.faeq.quadri@gmail.com
Objective: The study compares low-level laser therapy with topical medications for treating aphthous ulcers.

Methods: A search of articles in this systematic review was completed in six databases. Treatment and comparative groups comprised of patients subjected to laser therapy and topical medications, respectively. Two different treatment outcomes were considered; pain and size of the lesion. Risk of bias was assessed using the Revised Cochrane risk-of-bias tool for randomized trials.

Results: From 109 articles, five randomized control trials fulfilled the selection criteria. The overall sample comprised of 98 males and 232 females, with a mean age of 32.4 years. The laser therapies in each included study had different active media and varying wavelengths. Topical medication used in the comparative group were triamcinolone acetonide, amlexanox, granofurin, and solcoseryl. Findings showed that patients who reported lower pain and decreased aphthous ulcer lesions were more in the laser therapy group than in the topical medication group.

Conclusion: Low-level laser therapy was better in treating aphthous ulcer lesions in comparison to topical medications, and all laser wavelengths in the included reports were seen to be effective. However, the results should be interpreted with caution, because no study demonstrated low-risk of bias in all the assessed domains.

Keywords: aphthous ulcer, recurrent aphthous stomatitis, low-level laser therapy, systematic review, evidence-based practice

\section{Introduction}

Aphthous ulcer (AU), also known as recurrent aphthous stomatitis (RAS), is a painful, benign, inflammatory lesion of the oral mucosa. ${ }^{1}$ It is one of the most prevalent diseases in the oral cavity of adults, ${ }^{2}$ and is reported to affect nearly $25 \%$ of them at least once in their lifetime. ${ }^{3}$ Amongst the three types; the smallest is the herpetiform ulcer, and the more prevalent is the minor aphthous or Mikulicz ulcer, which looks like an elongated lesion having a crateriform base, and is surrounded by a white-grey pseudo membrane. The third form is rare in comparison to the other two, and is called the major aphthous or the Sutton's ulcer. ${ }^{4,5}$ The experience of aphthous ulcer is painful, and may affect an individual's capacity to perform daily activities like eating and speaking. ${ }^{6}$ The pain exacerbates upon consumption of acidic foods or drinks, especially if the ulcers are near the throat or on the soft palate. $^{2}$ Maintaining good oral hygiene becomes an equally difficult task, and 
a recent study indicates the presence of commensal colonies of bacteria and other microorganisms in patients with aphthous ulcers. It further states that the oral microbiota of patients with aphthous ulcer is different from that of a healthy individual. ${ }^{7}$ With these it is evident that the presence of aphthous ulcers not only affects the oral health, but also hinders the daily performances, eventually impacting the oral health-related quality-of-life. ${ }^{8}$

Management and treatment of aphthous ulcers is challenging, as the etiology remains unclear. ${ }^{1}$ Distinct treatment modalities such as anti-inflammatory drugs, anesthetics, immune modulators, antibiotics, and a few herbal therapies, are being prescribed. ${ }^{9,10}$ A review by Belenguer-Guallar et $\mathrm{al}^{10}$ compared pharmacological and non-pharmacological methods of managing recurrent aphthous stomatitis. The authors stated that the treatment usually starts with topical medications such as antiseptics, anti-inflammatory agents, analgesics, antibiotics, anesthetics, corticosteroids, and few natural substances. If there is no change in the signs and symptoms, then systemic therapy with antibiotics, corticosteroids, and immune modulators are preferred. However, systemic drugs produce side-effects, and, in some instances, the patients are forced to suspend the therapy.

More recently, lasers have been used in treating aphthous ulcers. Reports also compared and contrasted different types of lasers. ${ }^{11}$ Among them, the low-level laser therapy is seen to produce analgesia, stimulate the healing process, and reduce the healing period. ${ }^{11-13}$ It is reported to be relatively safe with no clinical complications because of the low energy output, ${ }^{14,15}$ and the patients treated with low-level laser therapy were able to eat, drink, and brush their teeth normally just after 3 days of treatment. ${ }^{16,17}$ Though there are individual reports that demonstrate the benefits of using low-level laser therapy to treat aphthous ulcers, but they have not been appraised. Also, there is no substantial evidence to date that investigates the effectiveness of low-level laser therapy in comparison to topical medications. Thus, the current study aims to compare low-level laser therapy with topical medications for treating aphthous ulcers, and also to perform a qualitative assessment of the published reports.

\section{Materials and Methods Study Design}

The current systematic review was planned and carried out between November 2019 and April 2020. The guidelines provided by Preferred Reporting Items for Systematic Reviews and Meta-Analysis (PRISMA) were adopted so that substantial transparency is maintained in the selection process of the published reports. ${ }^{18}$

\section{Research Question (PICO)}

The following is the problem, intervention, comparison, and outcome (PICO) question addressed for the current study: "Is laser treatment more effective than the conventional topical medication in reducing the pain and size of aphthous ulcer lesions?" The disease or problem was the clinically diagnosed aphthous ulcer lesion. The intervention and comparison were laser therapy and topical medication, respectively. Two different outcomes, measured objectively (clinically) or subjectively (perceived), were pain and/or size of the lesion.

\section{Eligibility Criteria}

All the articles published to January 30, 2020, in English (as spoken and understood by all authors), irrespective of their study design (observational and experimental studies), were included. Moreover, studies that report lasers (with different wave lengths), and topical medications; benzalkonium chloride, choline salicylate, lignocaine, diclofenac, glucocorticoids, tetracycline, herbal medications, and/or combinations of any of these as a treatment option for aphthous ulcers were included in this review. Thoughtfully, the correspondences, commentaries, editorials, case reports, pilot studies, and animal studies were excluded as the quality of evidence provided by them is mostly weak.

\section{Search Strategy and Data Extraction}

The search process was completed independently by two investigators (MKA and MN), and any discrepancies in the lists of selected articles was intended to be crossexamined by another investigator (MFAQ) who was not involved in the search process. The electronic search of the published articles was conducted in the Web of Science (WoS), PubMed (Medline), Scopus, Embase, Cochrane, and Google Scholar databases. Keywords/Mesh-terms that were utilised in different combinations to obtain the relevant articles are reported in Table 1. A manual search of references from the included articles was additionally carried out. A data extraction chart provided online by Cochrane collaboration was used by two investigators (MFAQ and HG) to report on the author names, year of publication, study design, location/study setting, type of ulcer, treatment details, outcomes, side-effects, and time duration of follow-up (Table 2). 
Table I Search Terms and Strategies

\begin{tabular}{|c|c|c|}
\hline $\begin{array}{l}\text { Search } \\
\text { Strategy }\end{array}$ & $\begin{array}{l}\text { Search Terms and Boolean } \\
\text { Operators }\end{array}$ & $\begin{array}{l}\text { Number of } \\
\text { Articles } \\
\text { Retrieved }\end{array}$ \\
\hline \#I & $\begin{array}{l}\text { Aphthous ulcer OR aphthous } \\
\text { stomatitis OR recurrent Aphthous } \\
\text { stomatitis }\end{array}$ & \\
\hline \#2 & Benzalkonium chloride & \\
\hline \#3 & Choline salicylate & \\
\hline$\# 4$ & Lignocaine OR lidocaine & \\
\hline \#5 & Diclofenac & \\
\hline \#6 & Glucocorticoids & \\
\hline \#7 & Tetracyclines & \\
\hline$\# 8$ & Laser* & \\
\hline \#9 & $\begin{array}{l}\text { Low level laser therapy (LLLT) OR } \\
\text { photobiomodulation }\end{array}$ & \\
\hline \#7 & $\# I$ AND \#8 & 83 \\
\hline$\# 8$ & $\# I$ AND \#9 & 22 \\
\hline \#9 & $\# I$ AND \#2 AND \#3 AND \#4 & I \\
\hline$\# 10$ & $\#$ I AND \#2 & 2 \\
\hline \#II & \#I AND \#3 & 3 \\
\hline$\# 12$ & $\#$ I AND \#4 & 22 \\
\hline$\# 13$ & $\# I$ AND \#5 & 0 \\
\hline$\# 14$ & \#I AND \#6 & 2 \\
\hline \multirow[t]{2}{*}{$\# 15$} & $\# I$ AND \#7 & I \\
\hline & Total hits & 136 \\
\hline
\end{tabular}

\section{Data Synthesis and Assessment of Risk of Bias}

For the studies that were included, a narrative and tabular synthesis of data was carried out. The assessment of the risk of bias for the eligible studies was performed independently by two investigators (MFAQ and MFAQ), using the criteria provided by the Revised Cochrane risk-of-bias tool for randomized trials (RoB2). ${ }^{19}$ The domains for assessment included the risk of bias arising from; the randomization process (selection bias), deviations from the intended interventions (selection bias), missing outcome data (attrition bias), measurement of the outcome (detection bias), and selection of the reported result (reporting bias). The "low", "some concerns", or "high", perceived judgments corresponded to the information available from the published articles (Table 3). The agreement of scores from both the authors was assessed using the intraclass correlation coefficient ( $\mathrm{r}$ ).

\section{Results}

\section{Study Identification and Screening}

The search of articles from the aforementioned databases resulted in a total of 136 hits, which was consistent between the two independent search processes. About 27 duplicates were removed, and the remaining 109 articles were screened. From these, full texts of three articles were not available. ${ }^{20-22}$ Finally, five articles were eligible for data extraction and quality appraisals (Figure 1).

\section{General Characteristics of the Included Studies}

The overall mean age of the study participants from all five studies was 32.4 years; 98 were male, and 232 were female. The study settings with the increasing order of their date of publications were; Turkey in 2009, ${ }^{11}$ Brazil in 2010, ${ }^{23}$ Bulgaria in 2014, ${ }^{24}$ India in $2016,{ }^{25}$ and Egypt in $2016 .{ }^{26}$ The included studies were randomized clinical trials with a cumulative sample of $330(\mathrm{~N})$, of which 155 patients were treated with laser therapy, 145 with topical medications, 15 underwent a placebo treatment, and the remaining 15 were treated with herbal medications.

\section{Description of Laser and Topical Treatments}

The laser therapies in each of the included studies had different active media. For instance, the therapy with diode lasers used a semiconductor diode as an active medium, the Nd:YAG laser had neodymium-doped $(\mathrm{Nd})$ yttrium aluminium garnet (YAG) crystals, and the InGaA1P laser had aluminium gallium arsenide as the active medium. Subsequently, the dosage for laser therapy in the treatment groups and the topical medication in the comparative groups were also distinct (Table 2). Tezel et $\mathrm{al}^{11}$ used a Nd:YAG laser with a wavelength of $1.064 \mathrm{~nm}$ and compared it with triamcinolone acetonide, while De Souza et $\mathrm{al}^{23}$ used an InGaA1P diode laser with $670 \mathrm{~nm}$ and compared it to triamcinolone acetonide. Jijin et $\mathrm{al}^{25}$ used an AMD laser $(810 \mathrm{~nm})$ compared with Amlexanox. Nasry et $\mathrm{al}^{26}$ used a diode laser $(970 \mathrm{~nm})$, comparing it with a herbal paste and Amlexanox, and, finally, Lalabonova and Daskalov ${ }^{24}$ used a diode laser with different wavelengths $(658 \mathrm{~nm})$ and compared it with 
Table 2 Description on Study Setting, Sample, Exposure, Outcome, and Conclusion of the Included Studies

\begin{tabular}{|c|c|c|c|c|c|c|c|}
\hline Item & $\begin{array}{l}\text { Author, } \\
\text { Year }\end{array}$ & $\begin{array}{l}\text { Study } \\
\text { Setting }\end{array}$ & $\begin{array}{l}\text { Sample } \\
\text { Description }\end{array}$ & Laser Treatment & $\begin{array}{l}\text { Topical } \\
\text { Medication }\end{array}$ & Follow Up & $\begin{array}{l}\text { Conclusion (Healing Time, } \\
\text { Pain, Size of Ulcer, } \\
\text { Reoccurrence) }\end{array}$ \\
\hline I & $\begin{array}{l}\text { Tezel et al, } \\
2009^{11}\end{array}$ & Turkey & $\begin{array}{l}\text { Total sample: } \\
\mathrm{n}=20 \\
\text { Male }=7 \\
\text { Female }=13 \\
\text { Laser group: } \\
\mathrm{n}=10 \\
\text { Male }=3 \\
\text { Female }=7 \\
\text { Topical } \\
\text { medication } \\
\text { group: } \\
\mathrm{n}=10 \\
\text { Male }=4 \\
\text { Female }=6\end{array}$ & $\begin{array}{l}\text { Anesthetic Gel } \\
\text { (articaine } 4 \% \text { ) + Nd: } \\
\text { YAG laser I.064 nm } \\
\text { Dose: Under air- } \\
\text { cooling with 2-3 } \\
\text { minutes duration. }\end{array}$ & $\begin{array}{l}\text { Triamcinolone } \\
\text { Acetonide. } \\
\text { Dose: Three } \\
\text { times daily for } \\
\text { I week. }\end{array}$ & $\begin{array}{l}\text { Days I, 4, } \\
\text { and } 7\end{array}$ & $\begin{array}{l}\text { Pain: } \\
\text { Laser - immediate pain relief and } \\
\text { faster healing } \\
\text { Topical medication group - gradual } \\
\text { reduction on day } 5 . \\
\text { Patient preference: } \\
\text { Significant in Laser group } \\
\text { Post-treatment complications } \\
\text { (chewing, speaking lower in Laser } \\
\text { group) } \\
\text { Erythema - no difference in both } \\
\text { groups. }\end{array}$ \\
\hline 2 & $\begin{array}{l}\text { De Souza } \\
\text { et al, } \\
2010^{23}\end{array}$ & Brazil & $\begin{array}{l}\text { Total sample: } \\
\mathrm{n}=20 \\
\text { Male }=8 \\
\text { Female }=12 \\
\text { Laser group: } \\
\mathrm{n}=15 \\
\text { Topical } \\
\text { medication } \\
\text { group: } \\
\mathrm{n}=5 \\
\text { Age: up to } 70 \\
\text { years }\end{array}$ & $\begin{array}{l}\text { InGaAIP } \\
\text { diode laser, } 670 \mathrm{~nm} \text {. } \\
\text { Dose: I minute, laser } \\
\text { pen touching the } \\
\text { surface of lesion. }\end{array}$ & $\begin{array}{l}\text { Triamcinolone } \\
\text { acetonide } \\
\text { administered } \\
\text { four } \\
\text { times daily, as } \\
\text { long as lesion } \\
\text { persisted. }\end{array}$ & $\begin{array}{l}\text { Day I to day } \\
7\end{array}$ & $\begin{array}{l}\text { Pain: } \\
86.6 \% \text { of the patients, having } \\
\text { undergone laser treatment, } \\
\text { reported a reduction in pain in the } \\
\text { same session }(P=0.0006) . \\
\text { Regression time: } \\
\text { No significant difference observed } \\
\text { between the two groups. }\end{array}$ \\
\hline 3 & $\begin{array}{l}\text { Lalabonova } \\
\text { and } \\
\text { Daskalov., } \\
2014^{24}\end{array}$ & Bulgaria & $\begin{array}{l}\text { Total sample: } \\
\mathrm{n}=\mid 80 \\
\text { Male=31 } \\
\text { Female }=149 \\
\text { Mean age: } \\
43.01(1.05) \\
\text { years }\end{array}$ & $\begin{array}{l}\text { SIX Laser TS } \\
\text { diode laser }-658 \mathrm{~nm} \text {. } \\
\text { Dose: One session } \\
\text { a day until symptoms } \\
\text { abated. }\end{array}$ & $\begin{array}{l}\text { Granofurin } \\
\text { and } \\
\text { Solcoseryl. } \\
\text { Dose: Twice } \\
\text { daily until } \\
\text { symptoms } \\
\text { disappeared. }\end{array}$ & $\begin{array}{l}\text { Days I, 2, 3, } \\
\text { and } 5\end{array}$ & $\begin{array}{l}\text { Pain: } \\
\text { Laser group: } \\
\text { Day 3=100\% patients pain free } \\
\text { Topical medication group: } \\
\text { Day 5=44.4\% pain free } \\
\text { Erythema: } \\
\text { Laser group: } \\
\text { Day 3=100\% patients with no } \\
\text { erythema } \\
\text { Topical medication group } \\
\text { Day 5=22.3\% patients with no } \\
\text { erythema } \\
\text { Epithelization: } \\
\text { Laser group: } \\
\text { Day } 5=75.6 \% \text { of patients with } \\
\text { complete epithelization. } \\
\text { Topical medication group: } \\
\text { Day } 5=37.8 \% \text { patients with } \\
\text { complete epithelization. }\end{array}$ \\
\hline
\end{tabular}

(Continued) 
Table 2 (Continued).

\begin{tabular}{|c|c|c|c|c|c|c|c|}
\hline Item & $\begin{array}{l}\text { Author, } \\
\text { Year }\end{array}$ & $\begin{array}{l}\text { Study } \\
\text { Setting }\end{array}$ & $\begin{array}{l}\text { Sample } \\
\text { Description }\end{array}$ & Laser Treatment & $\begin{array}{l}\text { Topical } \\
\text { Medication }\end{array}$ & Follow Up & $\begin{array}{l}\text { Conclusion (Healing Time, } \\
\text { Pain, Size of Ulcer, } \\
\text { Reoccurrence) }\end{array}$ \\
\hline 4 & $\begin{array}{l}\text { Jijin et al, } \\
2016^{25}\end{array}$ & India & $\begin{array}{l}\text { Total sample: } \\
\mathrm{n}=50 \\
\text { Male=29 } \\
\text { Female=2I } \\
\text { Laser group: } \\
\mathrm{n}=25 \\
\text { Male }=14 \\
\text { Female=1 } \\
\text { Topical } \\
\text { medication } \\
\text { group: } \\
\mathrm{n}=25 \\
\text { Male=15 } \\
\text { Female }=10 \\
\text { Age: } 15-55 \\
\text { years }\end{array}$ & $\begin{array}{l}\text { AMD laser } 810 \mathrm{~nm} \\
\text { Dose: } 30 \text { seconds, } \\
\text { and } 3 \text { times with } 2 \\
\text { minute interval. } \\
\text { Applied twice } \\
\text { after day I day of } \\
\text { treatment, followed } \\
\text { by day } 3 \text { and day } 7 .\end{array}$ & $\begin{array}{l}5 \% \\
\text { Amlexanox } \\
\text { given four } \\
\text { times } \\
\text { daily for } 7 \\
\text { days. }\end{array}$ & $\begin{array}{l}\text { Days I, 3,and } \\
7\end{array}$ & $\begin{array}{l}\text { Pain: } \\
\text { The mean pain score was } \\
\text { significantly less in the laser group } \\
\text { on day } 3 \text { than the Amlexanox group, } \\
\text { but not by day } 7 .\end{array}$ \\
\hline 5 & $\begin{array}{l}\text { Nasry et al, } \\
2016^{26}\end{array}$ & Egypt & $\begin{array}{l}\text { Total sample: } \\
\mathrm{n}=60 \\
\text { Male }=23 \\
\text { Female }=37 \\
\text { Age: } 19-40 \\
\text { years }\end{array}$ & $\begin{array}{l}\text { Group III: } \\
\text { Diode laser, } 970 \text { nm } \\
\text { Dose: } 30-45 \\
\text { seconds with I5-20 } \\
\text { seconds gap, } 4 \\
\text { sessions. } \\
\text { I, II, IV - applied } 4 \\
\text { times, } 5 \text { days. }\end{array}$ & $\begin{array}{l}\text { Group I: } \\
\text { Herbal paste } \\
\text { combination } \\
\text { (Glycyrrhiza } \\
\text { glabra + } \\
\text { Acacia } \\
\text { nilotica) } \\
\text { Group II: } \\
\text { Amlexanox } \\
\text { Tabs (2 mg) } \\
\text { Group IV: } \\
\text { Placebo } \\
\text { adhesive } \\
\text { tablets. }\end{array}$ & $\begin{array}{l}\text { Immediately, } \\
\text { and on days } \\
2 \text { and } 5\end{array}$ & $\begin{array}{l}\text { Pain and size: } \\
\text { Group III - Laser group reported } \\
\text { highest reduction in pain and ulcer } \\
\text { size on day } 5 . \\
\text { Group I showed reduction in pain } \\
\text { and size when compared to control } \\
\text { group IV. }\end{array}$ \\
\hline
\end{tabular}

Granofurin and Solcoseryl (Table 2). However, none of the included studies had reported plausible side-effects in the treatment or the comparative groups.

\section{Comparative Findings of Laser Therapy and Topical Medications}

The overall results showed that patients who reported lower pain and decreased aphthous ulcer lesions were more in the laser therapy group than in the topical medication group, at the end of a specified follow-up period in each of the included studies. This suggests that laser therapy was effective in reducing the pain and size of the lesions, compared to topical medications (Table 2). In general, the follow-up period was up to 7 days, except in the study performed by Lalabanov et al, ${ }^{24}$ where it was 5 days. Tezel et $\mathrm{al}^{11}$ and Jijin et $\mathrm{al}^{25}$ reported their results for days 1, 4, and 7, and days 1, 3, and 7, respectively. De Souza et $\mathrm{al}^{23}$ examined the outcomes for each day, from day 1 to 7 , and provided a cumulative result in favor of laser therapy. Finally, in the study by Nasry et $\mathrm{al}^{26}$ the laser group showed a decrease in pain and size of ulcer when checked on day 2 and 5.

\section{Risk of Bias}

The risk of bias was reported using the criteria provided by Revised Cochrane risk-of-bias tool for randomized trials (RoB2). ${ }^{19}$ The assessment was undertaken by two independent reviewers, and the risk of bias judgments for each 
Table 3 Risk of Bias Assessment Using the Cochrane Guidelines (RoB-2)

\begin{tabular}{|l|l|l|l|l|l|l|}
\hline Item & Signaling Question & $\begin{array}{l}\text { Tezel } \\
\text { et al, } \\
2009^{11}\end{array}$ & $\begin{array}{l}\text { Lalabonova } \\
\text { and Daskalov } \\
2014^{23}\end{array}$ & $\begin{array}{l}\text { De } \\
\text { Souza } \\
\text { et al, } \\
2010^{24}\end{array}$ & $\begin{array}{l}\text { Jijin } \\
\text { et al, } \\
2016^{25}\end{array}$ & $\begin{array}{l}\text { Nasry } \\
\text { et al, } \\
2016^{26}\end{array}$ \\
\hline
\end{tabular}

Domain I: Risk of bias arising from the randomization process (selection bias)

\begin{tabular}{|l|l|l|l|l|l|l|}
\hline I.I & Was the allocation sequence random? & Yes & No & No & No & No \\
\hline I.2 & $\begin{array}{l}\text { Was the allocation sequence concealed until participants were } \\
\text { enrolled and assigned to interventions? }\end{array}$ & No & No & No & No \\
\hline I.3 & $\begin{array}{l}\text { Did baseline differences between intervention groups suggest } \\
\text { a problem with the randomization process? }\end{array}$ & No & No & No & No & No \\
\hline Risk of bias judgment & $\begin{array}{l}\text { Some } \\
\text { concerns }\end{array}$ & Some concerns & $\begin{array}{l}\text { Some concerns } \\
\text { concerns }\end{array}$ & $\begin{array}{l}\text { Some } \\
\text { concerns }\end{array}$ \\
\hline
\end{tabular}

Domain 2: Risk of bias due to deviations from the intended interventions (selection bias)

\begin{tabular}{|c|c|c|c|c|c|c|}
\hline 2.1 & $\begin{array}{l}\text { Were participants aware of their assigned intervention during the } \\
\text { trial? }\end{array}$ & Yes & Yes & Yes & Yes & Yes \\
\hline 2.2 & $\begin{array}{l}\text { Were people delivering the interventions aware of participants' } \\
\text { assigned intervention during the trial? }\end{array}$ & Yes & Yes & Yes & Yes & Yes \\
\hline 2.3 & $\begin{array}{l}\text { Were there deviations from the intended intervention that arose } \\
\text { because of the trial context? }\end{array}$ & No & No & No & No & No \\
\hline 2.4 & Were these deviations likely to have affected the outcome? & N/A & N/A & N/A & N/A & N/A \\
\hline \multicolumn{2}{|c|}{ Risk of bias judgment } & $\begin{array}{l}\text { Some } \\
\text { concerns }\end{array}$ & Some concerns & $\begin{array}{l}\text { Some } \\
\text { concerns }\end{array}$ & $\begin{array}{l}\text { Some } \\
\text { concerns }\end{array}$ & $\begin{array}{l}\text { Some } \\
\text { concerns }\end{array}$ \\
\hline
\end{tabular}

Domain 3: Risk of bias due to missing outcome data (attrition bias)

\begin{tabular}{|l|l|l|l|l|l|l|}
\hline 3.1 & $\begin{array}{l}\text { Were data for this outcome available for all, or nearly all, } \\
\text { participants randomized? }\end{array}$ & Yes & Yes & Yes & Yes \\
\hline 3.2 & $\begin{array}{l}\text { Is there evidence that the result was not biased by missing outcome } \\
\text { data? }\end{array}$ & N/A & N/A & N/A & N/A & N/A \\
\hline 3.3 & Could missingness in the outcome depend on its true value? & N/A & N/A & N/A & N/A & N/A \\
\hline 3.4 & $\begin{array}{l}\text { Is it likely that missingness in the outcome depended on its true } \\
\text { value? }\end{array}$ & N/A & N/A & N/A & N/A & N/A \\
\hline Risk of bias judgment & Low risk & Low risk & Low risk & Low risk & Low risk \\
\hline
\end{tabular}

Domain 4: Risk of bias in measurement of the outcome (detection bias)

\begin{tabular}{|l|l|l|l|l|l|l|}
\hline 4.1 & Was the method of measuring the outcome inappropriate? & No & No & No & No & No \\
\hline 4.2 & $\begin{array}{l}\text { Could measurement or ascertainment of the outcome have differed } \\
\text { between intervention groups? }\end{array}$ & No & No & No & No & No \\
\hline 4.3 & $\begin{array}{l}\text { Were outcome assessors aware of the intervention received by } \\
\text { study participants? }\end{array}$ & Yes & Yes & Yes & Yes & No \\
\hline 4.4 & $\begin{array}{l}\text { Could assessment of the outcome have been influenced by } \\
\text { knowledge of intervention received? }\end{array}$ & Yes & Yes & Yes & Yes & No \\
\hline Risk of bias judgment & High risk & High risk & High risk & High risk & Low risk \\
\hline
\end{tabular}


Table 3 (Continued).

\begin{tabular}{|c|c|c|c|c|c|c|}
\hline Item & Signaling Question & $\begin{array}{l}\text { Tezel } \\
\text { et al, } \\
2009^{11}\end{array}$ & $\begin{array}{l}\text { Lalabonova } \\
\text { and Daskalov } \\
2014^{23}\end{array}$ & $\begin{array}{l}\text { De } \\
\text { Souza } \\
\text { et al, } \\
2010^{24}\end{array}$ & $\begin{array}{l}\text { Jijin } \\
\text { et al, } \\
2016^{25}\end{array}$ & $\begin{array}{l}\text { Nasry } \\
\text { et al, } \\
2016^{26}\end{array}$ \\
\hline \multicolumn{7}{|c|}{ Domain 5: Risk of bias in selection of the reported result (reporting bias) } \\
\hline 5.1 & $\begin{array}{l}\text { Were the data that produced this result analyzed in accordance with } \\
\text { a pre-specified analysis plan that was finalized before unblinded } \\
\text { outcome data were available for analysis? }\end{array}$ & Yes & Yes & Yes & Yes & Yes \\
\hline 5.2 & $\begin{array}{l}\text { Multiple eligible outcome measurements (eg scales, definitions, time } \\
\text { points) within the outcome domain? }\end{array}$ & Yes & Yes & Yes & Yes & Yes \\
\hline 5.3 & Multiple eligible analyses of the data? & No & No & No & No & No \\
\hline \multicolumn{2}{|c|}{ Risk of bias judgment } & Low risk & Low risk & Low risk & Low risk & Low risk \\
\hline
\end{tabular}

Notes: Data from Sterne et al. ${ }^{19}$

domain were almost identical (overall, $\mathrm{r}=0.91$ ); the minor discrepancies were sought by mutual consensus. The final judgments on the risk of bias for all five studies are presented in Table 3. Even though the studies had stated the use of randomization, they did not provide any description on the process, except for Tezel et al. ${ }^{11}$ Most studies had "some concerns" in the allocation bias domain. There was no missing data in any of the included studies; and only the study performed by Nasry et al had the outcomes assessed by blinded clinicians. ${ }^{26}$ Therefore, none of the included studies could be considered to be of high quality.

\section{Discussion}

Aphthous ulcer has an uncertain etiology, and, consequently, there is no definitive treatment. ${ }^{26}$ Numerous studies have been carried out to find the best and most effective treatment regime. Most treatments targeted pain reduction, decrease in size of the lesion, and inhibition of reoccurrence. The current review was carried out to determine if laser treatment was better than topical medication in addressing one or more of these treatment outcomes. The findings from the clinical trials included in this review unequivocally demonstrated that laser therapy was better than topical medications in relieving pain and decreasing its size.

Data on the use of laser therapy for aphthous ulcer is not extensive, and only a few studies have compared the effectiveness of laser therapy with other pharmacological treatments. ${ }^{27}$ Those studies had reported concurrent findings. It was observed that patients with aphthous ulcers had better tolerance for laser therapy (Nd:YAG) than topical corticosteroids (triamcinolone acetonide). ${ }^{11,28}$ In addition, the ulcers reappeared after treatment with topical corticosteroids, in contrast to no recurrence after laser therapy; and both groups were subjected to a constant follow-up period. ${ }^{28}$ De Souza et $\mathrm{al}^{23}$ in 2010 , reported immediate pain reduction and faster healing in patients treated with laser therapy, compared to the group treated with triamcinolone acetonide. Nearly $90 \%$ of patients exposed to laser treatment in the study performed by Lalabonova and Daskalov $^{24}$ were relieved from pain and erythema on the second day, whereas $55 \%$ of the patients in the topical ointment group (Granofurin and solcoseryl) reported pain until day 5 of the treatment. However, in the study by Jijin et $\mathrm{al}^{25}$ intergroup comparison to assess the size of the lesion demonstrated non-significant findings, and the medication group had received 5\% Amlexanox oral paste.

Only one study to date has compared three treatment categories, which included herbal paste (Glycyrrhiza glabra and Acacia nilotica), conventional medication (Amlexanox 5\%), and laser irradiation. ${ }^{26}$ Study participants reported lower pain scores and demonstrated better reduction in the ulcer size in the Amlexanox and Laser groups, compared to the herbal paste group. Amongst all, the laser group showed a higher proportion of patients with lower pain scores and reduced ulcer size. ${ }^{26}$ This effective result of Amlexanox 5\% was also shown in another study where it was compared with a combination of benzalkonium chloride, choline salicylate, and lignocaine. Although the patients in both groups showed a significant reduction in the number, size, and ulcer pain when compared to the baseline recordings, patients treated 


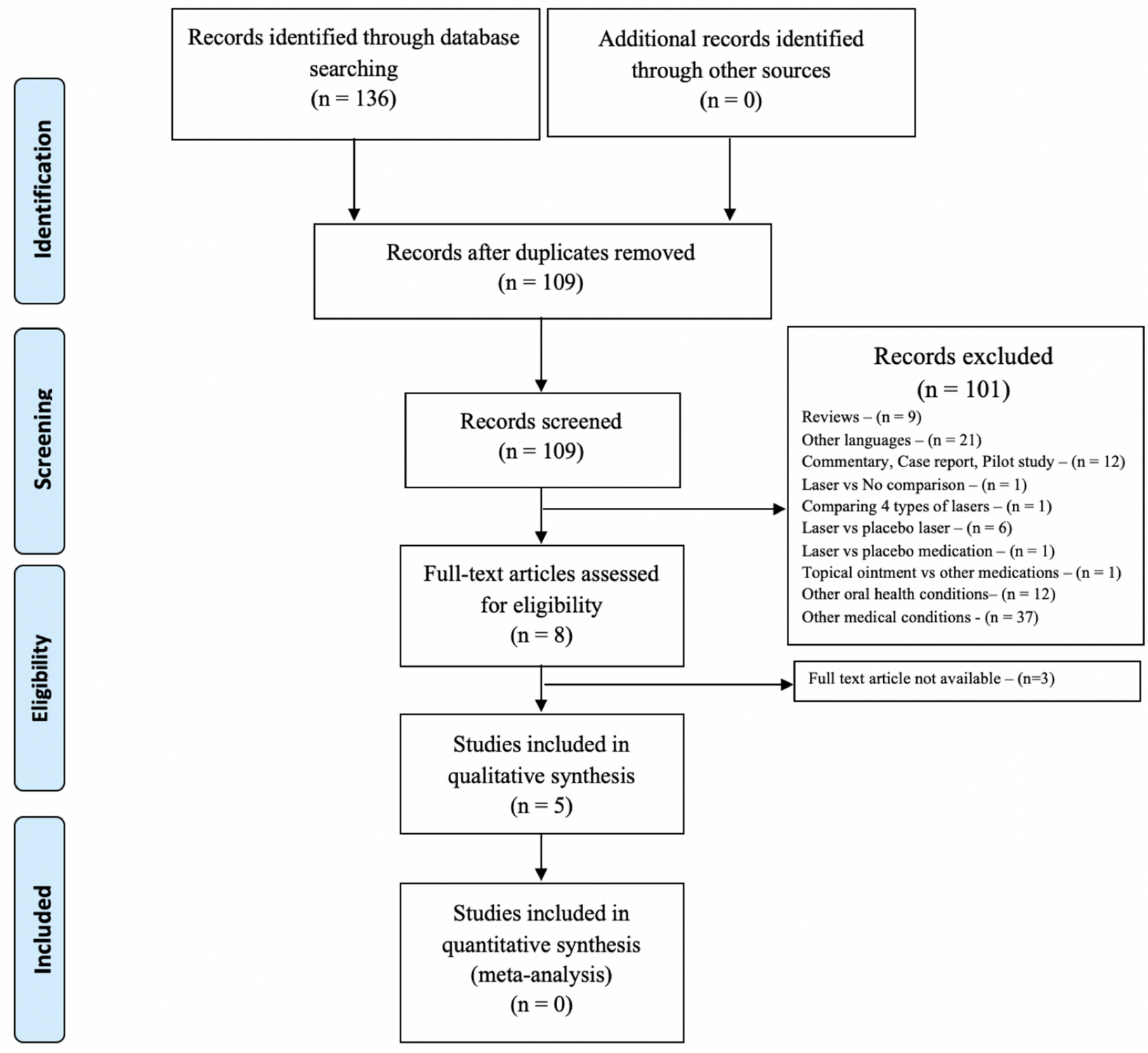

Figure I PRISMA flow chart illustrating the study selection process.

Notes: PRISMA figure adapted from Liberati A, Altman D, Tetzlaff J, et al. The PRISMA statement for reporting systematic reviews and meta-analyses of studies that evaluate health care interventions: explanation and elaboration. Journal of clinical epidemiology. 2009;62(10). Creative Commons.

with Amlexanox 5\% showed a significant difference between the groups. ${ }^{29}$

The effective dose of laser in each of the studies was different and dependent on the type of laser utilized. Rocca et al, ${ }^{30}$ upon comparing the wavelengths (Er:YAG, Diode lasers $-450 \mathrm{~nm}, 635 \mathrm{~nm}, 808 \mathrm{~nm}$ ) had shown that a wavelength of $635 \mathrm{~nm}$ was more effective in relieving pain. In addition, where lidocaine was applied before the laser therapy, the pain reduction was more substantial. ${ }^{31}$ In order to judge the healing time, two studies matched placebo laser therapy with $\mathrm{CO}_{2}$ laser therapy and indicated that the healing time was much shorter in patients treated with $\mathrm{CO}_{2}$ therapy; ${ }^{12,13}$ however, another study performed by Sattayut et $\mathrm{al}^{32}$ reported no significant difference in the healing time and pain level between the $\mathrm{CO}_{2}$ laser and placebo groups. Thus, a substantial evidence on the dose of lasers is warranted, and eventually the difference in the type and dose of lasers in each included study did not facilitate the meta-analysis of the numerical data.

Further, multivitamins are prescribed along with laser therapy; however, the evidence supporting their use is ambiguous. With the assumption that aphthous 
ulcer lesions are related to vitamin B 12 deficiency, a randomized double blind placebo-controlled trial was carried out by Volkov et $\mathrm{al}^{33}$ and, after 4 months of treatment, it was observed that vitamin B12 supplements were effective. In accordance to this, Yasui et $\mathrm{al}^{34}$ also suggested the use of Vitamin $\mathrm{C}$ in treating minor aphthous ulcers. Furthermore, studies have also reviewed the use of omega $3(1,000 \mathrm{mg})$ for minor aphthous ulcers, and reported a reduction in the ulcer duration and pain scores. ${ }^{35,36}$ On the contrary, some studies disagree with the use of multivitamins, as no significant difference was observed upon its comparison to a placebo effect. ${ }^{37,38}$ Accordingly, Lalla et $\mathrm{al}^{37}$ suggested not to prescribe multivitamins on a routine basis to treat aphthous ulcers. Nevertheless, there are studies that recommend preclinical examinations of R.B.C count, vitamin B12 levels, and levels of folic acid in the body, as their deficiency may inhibit the effectiveness of the therapy. ${ }^{39-41}$

To the best of our knowledge, this is the first systematic review undertaken to compare the effectiveness of laser therapy and topical medications in the treatment of aphthous ulcers. The earlier literature review by Vale (2015) had concurrent findings, but did not include reports from at least three studies. ${ }^{11,23,24} \mathrm{Next}$, the reviews by Najeeb et $\mathrm{al}^{27}$, and Han et al42 stated the effectiveness of lowlevel laser therapy, but did not intend to compare it with topical medications. These results, although similar, were not suitable to compare and contrast with the findings from the current systematic review due to evident reasons. The risk of bias assessment was also an important aspect of this review, as it provided the scores for the quality of research conducted. Although the results show that laser therapy was better in reducing the pain and size of the lesion, the results should be interpreted in accordance with the limitations of the studies included in the review. The risk of bias assessment judgment inferred that most of the studies did not describe how the randomization process was conducted. In addition, four out of five studies did not have a blinded investigator to assess the outcome. Cochrane guidelines state that each step in the methodology should be clearly explained to achieve a low risk score in the five domains of assessment. Therefore, further evidence using robust methodologies is warranted to substantiate the effectiveness of laser therapy over other treatment approaches. Also, the randomized control trials should consider reporting the potential side-effects that are experienced by the patients while undergoing laser therapies and/ or treatment by medication. Finally, it is highly recommended that a general clinical protocol be derived for the use of laser therapy in treating aphthous ulcer lesions.

\section{Conclusion}

In conclusion, low-level laser therapy was better in treating aphthous ulcer lesions in comparison to topical medications, and all laser wavelengths in the included reports were seen to be effective. However, the results should be interpreted with caution, because none of the included studies demonstrated a low-risk of bias in all the assessed domains.

\section{Knowledge Transfer Statement}

The current study provides an insight to the clinicians on the treatment of aphthous ulcers by comparing low-level laser therapy with the commonly prescribed topical medications. It is observed that the patients who reported lower pain and decreased aphthous ulcer lesions were more in the laser therapy group than in the topical medication group.

\section{Author Contributions}

All authors contributed to design, implement, and draft or revise the article, have agreed on the journal to which the article will be submitted, gave final approval of the version to be published, and agree to be accountable for all aspects of the work.

\section{Funding}

The current review did not receive funds from any outside source.

\section{Disclosure}

The authors of the current review do not have any competing interests to declare.

\section{References}

1. Edgar NR, Saleh D, Miller RA. Recurrent aphthous stomatitis: a review. J Clin Aesthet Dermatol. 2017;10(3):26-36.

2. Syed V. Comprehensive review on aphthous ulcers of oral cavity. Int J Med Health Res. 2017;3(5):1-3.

3. Patil S, Reddy SN, Maheshwari S, Khandelwal S, Shruthi D, Doni B. Prevalence of recurrent aphthous ulceration in the Indian population. J Clin Exp Dent. 2014;6(1):e36-e40. doi:10.4317/jced.51227

4. Andreas ANE-H, Christiana M, Marion P, Mohammed BA-N, Christos CZ. The treatment of chronic recurrent oral aphthous ulcers Dtsch Arztebl Int. 2014;111(40):665-673.

5. Queiroz SIML, Silva MVAD, Medeiros AMC, Oliveira PT, Gurgel BCV, Silveira É. Recurrent aphthous ulceration: an epidemiological study of etiological factors, treatment and differential diagnosis. An Bras Dermatol. 2018;93(3):341-346. doi:10.1590/ abd1806-4841.20186228 
6. Tarakji B, Gazal G, Al-Maweri SA, Azzeghaiby SN, Alaizari N. Guideline for the diagnosis and treatment of recurrent aphthous stomatitis for dental practitioners. J Int Oral Health. 2015;7 (5):74-80.

7. Bankvall M, Sjöberg F, Gale G, Wold A, Jontell M, Östman S. The oral microbiota of patients with recurrent aphthous stomatitis. J Oral Microbiol. 2014;6:25739. doi:10.3402/jom.v6.25739

8. Zwiri AM. Anxiety, depression and quality of life among patients with recurrent aphthous ulcers. J Contemp Dent Pract. 2015;16 (2):112-117. doi:10.5005/jp-journals-10024-1646

9. Kürklü-Gürleyen E, Öğüt-Erişen M, Çakır O, Uysal Ö, Ak G. Quality of life in patients with recurrent aphthous stomatitis treated with a mucoadhesive patch containing citrus essential oil. Patient Prefer Adherence. 2016;10:967-973. doi:10.2147/PPA.S106530

10. Belenguer-Guallar I, Jiménez-Soriano Y, Claramunt-Lozano A. Treatment of recurrent aphthous stomatitis. A literature review. J Clin Exp Dent. 2014;6(2):e168-e174. doi:10.4317/jced.51401

11. Tezel A, Kara C, Balkaya V, Orbak R. An evaluation of different treatments for recurrent aphthous stomatitis and patient perceptions: nd:YAG laser versus medication. Photomed Laser Surg. 2009;27 (1):101-106. doi:10.1089/pho.2008.2274

12. Prasad RS, Pai A. Assessment of immediate pain relief with laser treatment in recurrent aphthous stomatitis. Oral Surg Oral Med Oral Pathol Oral Radiol. 2013;116(2):189-193. doi:10.1016/j.oooo.2013.02.011

13. Zand N, Ataie-Fashtami L, Djavid GE, et al. Relieving pain in minor aphthous stomatitis by a single session of non-thermal carbon dioxide laser irradiation. Lasers Med Sci. 2009;24(4):515-520. doi:10.1007/ s10103-008-0555-1

14. Akerzoul N, Chbicheb S. Low laser therapy as an effective treatment of recurrent aphtous ulcers: a clinical case reporting two locations. Pan Afr Med J. 2018;30:205.

15. Anand V, Gulati M, Govila V, Anand B. Low level laser therapy in the treatment of aphthous ulcer. Indian J Dent Res. 2013;24 (2):267-270. doi:10.4103/0970-9290.116691

16. Vale FA, Moreira MS, Almeida FC, Ramalho KM. Low-level laser therapy in the treatment of recurrent aphthous ulcers: a systematic review. Sci World J. 2015;2015.

17. Aggarwal H, Singh MP, Nahar P, Mathur H, Gv S. Efficacy of low-level laser therapy in treatment of recurrent aphthous ulcers a sham controlled, split mouth follow up study. J Clin Diagn Res. 2014;8(2):218-221.

18. Liberati A, Altman DG, Tetzlaff J, et al. The PRISMA statement for reporting systematic reviews and meta-analyses of studies that evaluate health care interventions: explanation and elaboration. PLoS Med. 2009;6(7):e1000100.

19. Sterne JAC, Savović J, Page MJ, et al. RoB 2: a revised tool for assessing risk of bias in randomised trials. BMJ. 2019;366:14898. doi:10.1136/bmj.14898

20. Descroix V, Coudert AE, Vigé A, et al. Efficacy of topical $1 \%$ lidocaine in the symptomatic treatment of pain associated with oral mucosal trauma or minor oral aphthous ulcer: a randomized, double-blind, placebo-controlled, parallel-group, single-dose study. J Orofac Pain. 2011;25(4):327-332.

21. Giammarinaro E, Cosola S, Oldoini G, et al. Local formula with mucoadhesive property: a randomized clinical trial of a therapeutic agent for the treatment of oral aphthous ulcers. J Contemp Dent Pract. 2019;20(11):1249-1253. doi:10.5005/jp-journals-10024-2709

22. Convissar RA, Massoumi-Sourey M. Recurrent aphthous ulcers: etiology and laser ablation. Gen Dent. 1992;40(6):512-515.

23. De Souza TO, Martins MA, Bussadori SK, et al. Clinical evaluation of low-level laser treatment for recurring aphthous stomatitis. Photomed Laser Surg. 2010;28(Suppl 2):S85-S88. doi:10.1089/pho.2009.2661

24. Hristina Lalabonova HD, Daskalov H. Clinical assessment of the therapeutic effect of low-level laser therapy on chronic recurrent aphthous stomatitis. Biotechnol Biotechnol Equip. 2014;28 (5):929-933. doi:10.1080/13102818.2014.966526
25. Jijin MJ, Rakaraddi M, Pai J, et al. Low-level laser therapy versus 5\% amlexanox: a comparison of treatment effects in a cohort of patients with minor aphthous ulcers. Oral Surg Oral Med Oral Pathol Oral Radiol. 2016;121(3):269-273. doi:10.1016/j. oooo.2015.11.021

26. Nasry SA, El Shenawy HM, Mostafa D, Ammar NM. Different modalities for treatment of recurrent aphthous stomatitis. A randomized clinical trial. J Clin Exp Dent. 2016;8(5):e517-e522.

27. Najeeb S, Khurshid Z, Zohaib S, Najeeb B, Qasim SB, Zafar MS. Management of recurrent aphthous ulcers using low-level lasers: a systematic review. Medicina. 2016;52(5):263-268. doi:10.1016/j. medici.2016.07.006

28. Arabaci T, Kara C, Ciçek Y. Relationship between periodontal parameters and Behçet's disease and evaluation of different treatments for oral recurrent aphthous stomatitis. J Periodontal Res. 2009;44 (6):718-725. doi:10.1111/j.1600-0765.2008.01183.x

29. Darshan DD, Kumar CN, Kumar AD, Manikantan NS, Balakrishnan D, Uthkal MP. Clinical study to know the efficacy of amlexanox 5\% with other topical antiseptic, analgesic and anesthetic agents in treating minor RAS. $J$ Int Oral Health. 2014;6(1):5-11.

30. Rocca JP, Zhao M, Fornaini C, Tan L, Zhao Z, Merigo E. Effect of laser irradiation on aphthae pain management: a four different wavelengths comparison. J Photochem Photobiol B. 2018;189:1-4. doi:10.1016/j.jphotobiol.2018.09.016

31. Colvard M, Kuo P. Managing aphthous ulcers: laser treatment applied. J Am Dent Assoc. 1991;122(6):51-53. doi:10.1016/S00028177(91)26017-1

32. Sattayut S, Trivibulwanich J, Pipithirunkarn N, Danvirutai N. A clinical efficacy of using $\mathrm{CO} 2$ laser irradiating to transparent gel on aphthous stomatitis patients. Laser Ther. 2013;22(4):283-289. doi:10.5978/islsm.13-OR-24

33. Volkov I, Rudoy I, Freud T, et al. Effectiveness of vitamin B12 in treating recurrent aphthous stomatitis: a randomized, double-blind, placebo-controlled trial. J Am Board Fam Med. 2009;22(1):9-16. doi:10.3122/jabfm.2009.01.080113

34. Yasui K, Kurata T, Yashiro M, Tsuge M, Ohtsuki S, Morishima T. The effect of ascorbate on minor recurrent aphthous stomatitis. Acta Paediatr. 2010;99(3):442-445. doi:10.1111/j.1651-2227.2009.01628. $\mathrm{x}$

35. El Khouli AM, El-Gendy EA. Efficacy of omega-3 in treatment of recurrent aphthous stomatitis and improvement of quality of life: a randomized, double-blind, placebo-controlled study. Oral Surg Oral Med Oral Pathol Oral Radiol. 2014;117(2):191-196.

36. Nosratzehi T, Akar A. Efficacy of omega-3 in treatment of recurrent aphthous stomatitis: a randomised, double-blind, Placebo-controlled Study. Chin J Dent Res. 2016;19(3):159-164.

37. Lalla RV, Choquette LE, Feinn RS, et al. Multivitamin therapy for recurrent aphthous stomatitis: a randomized, double-masked, placebo-controlled trial. J Am Dent Assoc. 2012;143(4):370-376. doi:10.14219/jada.archive.2012.0179

38. Spivakovsky S, Keenan AV. No effect seen for multivitamin therapy on recurrent aphthous stomatitis patients. Evid Based Dent. 2013;14 (1):26.

39. Chavan M, Jain H, Diwan N, Khedkar S, Shete A, Durkar S. Recurrent aphthous stomatitis: a review. J Oral Pathol Med. 2012;41(8):577-583. doi:10.1111/j.1600-0714.2012.01134.x

40. Preeti L, Magesh K, Rajkumar K, Karthik R. Recurrent aphthous stomatitis. $J$ Oral Maxillofac Pathol. 2011;15(3):252-256. doi:10.4103/0973-029X.86669

41. Liang MW, Neoh CY. Oral aphthosis: management gaps and recent advances. Ann Acad Med Singapore. 2012;41(10):463-470.

42. Han M, Fang H, Li QL, Cao Y, Xia R, Zhang ZH. Effectiveness of laser therapy in the management of recurrent aphthous stomatitis: a systematic review. Scientifica (Cairo). 2016;2016:9062430. 


\section{Publish your work in this journal}

The Journal of Multidisciplinary Healthcare is an international, peerreviewed open-access journal that aims to represent and publish research in healthcare areas delivered by practitioners of different disciplines. This includes studies and reviews conducted by multidisciplinary teams as well as research which evaluates the results or conduct of such teams or healthcare processes in general. The journal

covers a very wide range of areas and welcomes submissions from practitioners at all levels, from all over the world. The manuscript management system is completely online and includes a very quick and fair peer-review system. Visit http://www.dovepress.com/testimonials. php to read real quotes from published authors. 